\title{
Evolution of Black-Tipped Tails in Weasels: Predator Confusion
}

\author{
Roger A. Powell
}

The American Naturalist, Vol. 119, No. 1. (Jan., 1982), pp. 126-131.

Stable URL:

http://links.jstor.org/sici?sici=0003-0147\%28198201\%29119\%3A1\%3C126\%3AEOBTIW\%3E2.0.CO\%3B2-6

The American Naturalist is currently published by The University of Chicago Press.

Your use of the JSTOR archive indicates your acceptance of JSTOR's Terms and Conditions of Use, available at

http://www.jstor.org/about/terms.html. JSTOR's Terms and Conditions of Use provides, in part, that unless you have obtained prior permission, you may not download an entire issue of a journal or multiple copies of articles, and you may use content in the JSTOR archive only for your personal, non-commercial use.

Please contact the publisher regarding any further use of this work. Publisher contact information may be obtained at http://www.jstor.org/journals/ucpress.html.

Each copy of any part of a JSTOR transmission must contain the same copyright notice that appears on the screen or printed page of such transmission.

The JSTOR Archive is a trusted digital repository providing for long-term preservation and access to leading academic journals and scholarly literature from around the world. The Archive is supported by libraries, scholarly societies, publishers, and foundations. It is an initiative of JSTOR, a not-for-profit organization with a mission to help the scholarly community take advantage of advances in technology. For more information regarding JSTOR, please contact support@ jstor.org. 


\section{EVOLUTION OF BLACK-TIPPED TAILS IN WEASELS: PREDATOR CONFUSION}

Contrasting coloration is widespread in the animal kingdom (Rothschild 1975). For many years, authors have suggested that contrasting coloration is often used to confuse predators (Hailman 1977; Mortensen 1918; Wickler 1968). Many insects, especially lepidopterans, and fishes have contrasting spots (deflection marks) which are believed to deflect a predator's attack away from vital body parts (Blest 1957; Hailman 1977; Robbins 1980; Wickler 1968). Use of contrasting coloration is common among mammals but use of such coloration to confuse predators has been the subject of controversy (Coblentz 1980; Hirth and McCullough 1977; Pitcher 1979; Smythe 1970, 1977).

Long-tailed weasels (Mustela frenata) and short-tailed weasels ( $M$. erminea) have black-tipped tails that contrast with the rest of their coloration. The contrast is especially sharp during winter when individuals in northern populations are white except for their black tail tips. Both of these species are small (weights range from ca. $100 \mathrm{~g}$ to ca. $300 \mathrm{~g}$; Hall 1951). A third species, the least weasel $(M$. nivalis), considerably smaller (ca. 40 to $60 \mathrm{~g}$ in North America; Hall 1951), also changes color during winter but does not have the black tail tip. Its tail is relatively much shorter than the tails of the other two species. Except for early speculations (Seton 1929; Stone and Cram 1902), there are no explanations in the literature for the black tail tips on weasels.

Weasels are subject to predation by many other predators (see review in Powell 1973) and occasionally predation may be a major factor in population regulation (Powell 1973). It has been suggested that at least during winter the black tail tip may enhance the cryptic nature of the white coloration and reduce predation on weasels by other predators (Powell 1978b; Stone and Cram 1902). Though in winter both weasels and snow are white, they are seldom the same shade. Snow color is affected by shadows, thaws, ice crystalline structure, and debris. As winter progresses, weasels often become stained yellow on their hips. Color differences, movement, and shadows make a moving weasel easy to see against the snow. The black tail tip, however, is more conspicuous than is the body of the weasel. This draws the attention of an observer toward the tail and thus makes the weasel's body considerably more difficult to see. Stone and Cram and I have hypothesized that the black tail tip will draw the attention of a potential predator, especially a diurnal avian predator that hunts primarily by sight, away from the weasel's body to its tail. An attacking predator may thus be more likely to miss the weasel and strike at the tail. I have also hypothesized that because least weasels are smaller and have such short tails, a black tail tip would be too close to the weasel and would not misdirect an attacking hawk (Powell 1978b). Because the grasping ability of hawks is not good enough to hold something as fine as the tail of a weasel, looking in museum collections for weasels missing parts of their tails does not give further insight into these hypotheses. 


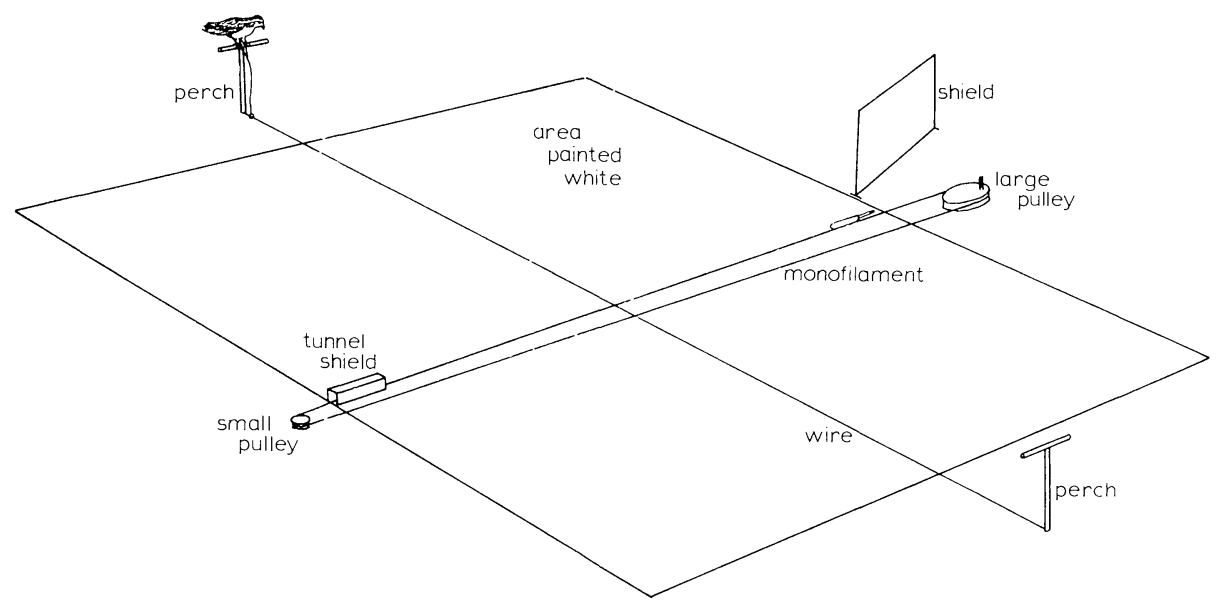

FIG. 1.-Diagram of experimental design. Hawks could fly from perch to perch connected to a wire by a $1.5-\mathrm{m}$ leash. A fake weasel was drawn across the area of the roof painted white on monofilament fishing line. The monofilament line was moved by turning the large pulley at a predetermined rate. A large wooden shield hid the observer and fake weasels from the hawk. The wooden tunnel shield hid the fake weasels from the hawks at the small pulley end of the system.

\section{METHODS}

Three red-tailed hawks (Buteo jamaicensis) were trained to attack models of weasels in white winter coats.

Two perches approximately $1.5 \mathrm{~m}$ high with a wire running along the ground between them were located $30 \mathrm{~m}$ apart on the flat, concrete roof of the Lion House at the Brookfield Zoo, Chicago Zoological Park, Brookfield, Illinois. The roof between the perches was painted white. Midway between the perches and perpendicular to a line between them, monofilament fishing line was stretched between two wooden pulleys which lay flat on the ground (fig. 1). Using a handle, one pully could be turned to pull the line across the roof.

During training and tests the hawks' jesses were attached with a 1.5 -m lead to the wire between the perches. Hawks were first trained to attack a brown, padded $8 \times 12 \times 20$-cm training dummy and dead white lab mice. The training dummy or a mouse was attached to the monofilament line and drawn across the hawks' field of vision. Successful attacks were rewarded with food. This turning rate was then used for all tests using that hawk.

Weasel models were made of cylinders of white artificial fur with solid pieces of styrofoam inside for shape and rigidity. Weasels' tails were made by sewing white fur once around a piece of wire $2 \mathrm{~mm}$ thick. Weasels were two sizes (male long-tailed weasel, $40 \mathrm{~cm}$ total length; male least weasel, $17 \mathrm{~cm}$ total length) with three color patterns (solid white, black tip on tail, black spot on back), making six color-size morphs (fig. 2). Black spots were made using black electrician's tape.

A total of 72 model weasel trials was presented to each hawk. Model weasels were equally divided between the six size-spot morphs and presented in random 

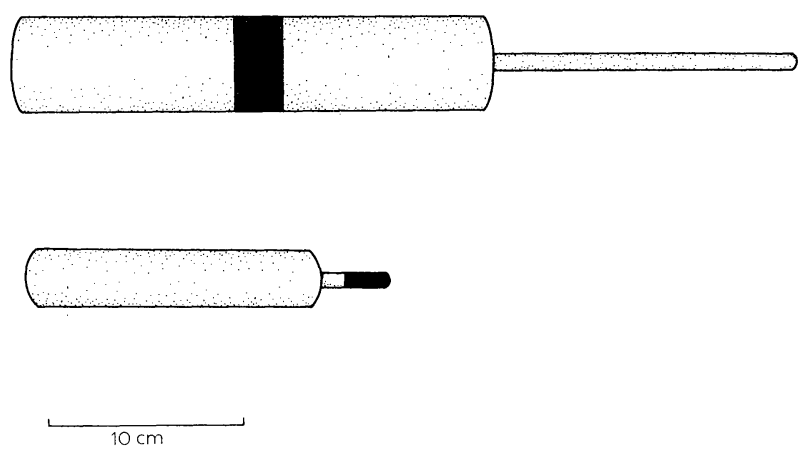

Fig. 2.-Examples of two fake weasel size-spot morphs: long-tail weasel with a back spot, least weasel with a tail spot.

order until morphs were presented 12 times each. Attack success was recorded for each weasel model presented.

\section{RESULTS}

The number of times each hawk missed each color-size morph is shown in table 1. Hawks always firmly grasped the fake weasels or were unable to grasp them at all. Long-tailed weasels with tail spots and least weasels with no spots were missed significantly more frequently by each hawk than the other color-size morphs (null hypothesis: each hawk missed all morphs equally frequently; $P \ll .001$, chisquare). Observers occasionally noted that hawks attempted to grasp the tail of the long-tailed, tail-spot morph but were unable to hold the tail because of poor dexterity and tail thinness; or hawks appeared to check their attack and miss at the last moment as though they had been surprised by some aspect of the weasel model.

\section{DISCUSSION}

The large weasel model with the black tail-spot was more difficult for the red-tailed hawks to catch than were the other two large morphs. This strongly

TABLE 1

Number of Times a Red-Tailed Hawk Missed a Fake Weasel of the Designated Size-Spot Morph

\begin{tabular}{|c|c|c|c|c|}
\hline \multirow[b]{2}{*}{ SIZE-SPOT MORPH } & \multicolumn{3}{|c|}{ HaWK } & \multirow[b]{2}{*}{ TOTAL } \\
\hline & $\# 1$ & $\# 2$ & \#3 & \\
\hline$\ldots \ldots \ldots \ldots \ldots$ & 1 & 1 & 0 & 2 \\
\hline Long-tail, tail spot $\ldots \ldots \ldots \ldots \ldots$ & 11 & 4 & 9 & 24 \\
\hline Long-tail, back spot $\ldots \ldots \ldots \ldots \ldots \ldots$ & 2 & 0 & 2 & 4 \\
\hline Least, no spot $\ldots \ldots \ldots \ldots \ldots \ldots$ & 9 & 7 & 9 & 25 \\
\hline Least, tail spot $\ldots \ldots \ldots \ldots \ldots \ldots \ldots$ & 1 & 0 & 1 & 2 \\
\hline Least, back spot $\ldots \ldots \ldots \ldots \ldots \ldots$ & 3 & 0 & 0 & 3 \\
\hline
\end{tabular}

NoTE.-Each kind of fake weasel morph was presented 12 times. 
supports the hypothesis that the black tail tip on white weasels serves to reduce predation on weasels by avian predators. Further support can be drawn from the observations on hawk behavior. The hawks did indeed sometimes attack the black tips on the tails and at other times the hawks appeared to notice suddenly that they were attacking something more than the black-tipped tail. I believe that the hawks hesitated because they suddenly saw the rest of the weasel model.

The results also support the hypothesis that least weasels have such short tails that a black spot could be disadvantageous and could increase mortality by predation. Apparently their small size slightly increases the time it takes for a hawk to perceive a least weasel, thus decreasing mortality as the result of predation. One might ask why least weasels do not have longer tails with black tips and thus reduce mortality even more. I can suggest that least weasels might be so small that they would be unable to keep a long tail warm during northern winters.

I am not suggesting that the only function of the black tail tip is to reduce predation by avian predators. It is possible that the black tail tips may help young weasels follow their mothers or that the tips may be used in intraspecific communication (S. Erlinge, personal communication). Least weasels in Europe are the size of short-tailed and sometimes even long-tailed weasels in North America but they still have short tails with no black spots. In addition, least weasels on both continents often have at the tips of their tails a small number of black hairs, which can be seen only upon close inspection. These variations in size and patterns of black tail tips are not explained by the research discussed here.

Weasels appear to have other adaptations for reducing mortality resulting from predation. Weasels hunt using erratic movement patterns (Powell 1978a, 1978b), thereby reducing movement predictability and potentially reducing capture success of avian predators attacking them (Powell 1978 a, 1978b).

Apparently, the black tail tips on white long-tailed weasels serve to confuse predators and to deflect an attack away from vital parts of the weasel. The black tail tip is not a pursuit invitation signal in the context of Smythe (1970) because the tail is always visible whether predators are near or far and whether a weasel is aware of a predator or not. Instead, the black spot confuses any predator that chooses to attack a long-tailed weasel, and functions as a deflection mark.

A deflection mark has not been recorded previously for a mammal, though deflection marks have been reported for many insects, fishes, and some reptiles (Hailman 1977; Mortensen 1918; Robinson 1969; Wickler 1968). Robbins (1980) and Wickler (1968), however, pointed out that almost none of the deflection marks have been tested; almost all support is from anecdotal evidence alone. Silberlied et al. (1980) have shown that accepted hypotheses on coloration as predator confusion devices do not always hold true when tested.

Deflection marks usually fit into one of two categories: false eyes or false heads. Blest (1957) and Robbins (1980) have tested false eye and false head hypotheses with Nymphalis io and Arawacus aetolus (Lepidoptera), respectively. For these species the deflection marks do appear to reduce predation. Wickler (1968) reported that a coral reef fish (Runula spp.) normally attacks the eyes of larger fish but will also attack false eyespots not located on a large fish's head.

In his discussion of prey defenses against predators that hunt by sight Robinson (1969) noted that vertebrate predators, especially birds, often orient their attacks 
toward the eyes of their prey and that many prey species have coloration that appears to hide their eyes. The yellow buntings Emberiza citrinella studied by Blest (1957) directed their attacks towards the eyespots painted onto meal worms. Smith (1976) found that motmots (Eumomota superciliosa) attacked the ends of wooden cylinders with painted eyespots. When the cylinders were moved with the eyespot ends leading, attacks were strongly oriented toward the leading ends. However, when the cylinders were moved "backward" the attacks were less clearly oriented toward the leading ends and were often directed toward the trailing eyespots. Thus, color patterns that mimic eyes may be effective deflection marks from many prey species, especially those preyed upon by birds, even though most of the supposed deflection marks have not been tested.

The black tail tip on a weasel does not closely resemble an eye but the contrasting color of the spot may be enough of a mimic to achieve the same results as an accurate false eye. Motmots directed attacks toward the end of wooden cylinders with contrasting coloration (Smith 1976). Whether the black tail tips of weasels appear as false eyes to red-tailed hawks or as very small black prey, or as something else, cannot be determined from this study. To the weasels it makes little difference; it works.

\section{ACKNOWLEDGMENTS}

Ron Snyder did almost all of the hawk training and collected about half of the data. The work could not have been done without him. Brookfield Zoo generously provided space for the research, the red-tailed hawks, and all of the construction materials and labor required for the research. Sam Erlinge, Dick Lanica, Doug Miller, Mal Whitsett, and two anonymous reviewers made helpful comments on early drafts of the manuscript. This is paper no. 6695 of the journal series of the North Carolina Agricultural Research Service.

\section{LITERATURE CITED}

Blest, A. D. 1957. The function of eyespot patterns in the Lepidotera. Behaviour 11:209-256.

Coblentz, B. E. 1980. On the improbability of pursuit invitation signals in mammals. Am. Nat. 115:438-442.

Hailman, T. P. 1977. Optical signals: animal communication and light. Indiana University Press, Bloomington.

Hall, E. R. 1951. American weasels. Univ. Kans. Publ. Mus. Nat. Hist. 4:1-466.

Hirth, D. H., and D. R. McCullough. 1977. Evolution of alarm signals in ungulates with special reference to white-tailed deer. Am. Nat. 111:31-42.

Mortensen, T. 1918. Observations on protective adaptations and habits, mainly in marine animals. Vidensk. Medd. Dan. Naturhist. Foren. 69:57-96.

Pitcher, T. 1979. He who hesitates, lives. Is stotting antiambush behavior? Am. Nat. 113:453-456.

Powell, R. A. 1973. A model for raptor predation on weasels. J. Mammal. 54:259-263. 1978a. A comparison of fisher and weasel hunting behavior. Carnivore 1(1):28-34. 1978b. Zig-zag-zap. Anim. Kingdom 81 (6):20-25.

Robbins, R. K. 1980. The lycaenid "false head" hypothesis: historical review and quantitative analysis. J. Lepid. Soc. 34:194-208.

Robinson, M. H. 1969. Defenses against visually hunting predators. Evol. Biol. 3:225-259. 
Rothschild, M. 1975. Remarks on carotenoids in the evolution of signals. Pages 20-52 in L. E. Gilbert and P. H. Raven, eds. Coevolution of animals and plants. University of Texas Press, Austin.

Seton, E. T. 1929. Lives of game animals. Doubleday, Doran, New York.

Silberlied, R. E., A. Aiello, and D. M. Windsor. 1980. Disruptive coloration in butterflies: lack of support in Anartia fatima. Science 209:617-619.

Smith, S. M. 1976. Predatory behavior of young turquoise-browed motmots, Eumomota superciliosa. Behaviour 56:309-320.

Smythe, N. 1970. On the existence of "pursuit invitation" signals in mammals. Am. Nat. 104:491494.

1977. The function of mammalian alarm advertising: social signals or pursuit invitation? Am. Nat. 111:191-194.

Stone, W., and W. E. Cram. 1902. American animals: a popular guide to the mammals of North America north of Mexico, with intimate biographies of the more familiar species. Doubleday, Page, New York.

Wickler, W. 1968. Mimicry in plants and animals. McGraw-Hill, New York.

\author{
DEPARTMENTS OF ZOOLOGY AND FORESTRY \\ North Carolina State University \\ Raleigh, North Carolina 27650
}

Submitted November 24, 1980; Revised May 21, 1981; Accepted June 19, 1981 